\title{
Preparation of Rutile Titanium Dioxide Pigment from Low-grade Titanium Slag pretreated by the $\mathrm{NaOH}$ Molten Salt Method
}

Liu Yahui ${ }^{\mathrm{a}, \mathrm{b}}$, Meng Fancheng, ${ }^{\mathrm{a}, \mathrm{b}}$, Fang Fuqiang ${ }^{\mathrm{a}, \mathrm{b}}$, Wang Weijing ${ }^{\mathrm{a}, \mathrm{b}}$, Wang Shuyi ${ }^{\mathrm{a}, \mathrm{b}}$, Wang Dong $^{\mathrm{a}, \mathrm{b}}$, Chu Jinglong ${ }^{\mathrm{a}, \mathrm{b}}$, Qi Tao ${ }^{\mathrm{a}, \mathrm{b} *}$

a National Engineering Laboratory for Hydrometallurgical Cleaner Production Technology, Beijing 100190, PR China

b Key Laboratory of Green Process and Engineering, Institute of Process Engineering, Chinese Academy of Sciences, Beijing 100190, PR China

\begin{abstract}
Low-grade titanium slag with a high accumulation of $\mathrm{Mg}, \mathrm{Al}, \mathrm{Si}$, and the refractory structure of spinel, was sodiumized-oxidized to make it usable in the sulfate process for $\mathrm{TiO}_{2}$ pigment production. In the sodiumized-oxidized process, the $\mathrm{Ti}_{3} \mathrm{O}_{5}$ and $\mathrm{Mg}_{2} \mathrm{SiO}_{4}$ transform into $\mathrm{Na}_{2} \mathrm{TiO}_{3}$ and $\mathrm{Na}_{2} \mathrm{MgSiO}_{4}$, respectively. From combined ICP-OES with XRD refinement of the molten $\mathrm{NaOH}$ intermediate, the ideal stoichiometric ratio of $\mathrm{NaOH}$ to slag was calculated to be $0.9: 1$. After acidolysis of the intermediate, the obtained $\mathrm{TiOSO}_{4}$ solution, with $\mathrm{Mg}^{2+}$ and $\mathrm{Al}^{3+}$ impurities, was hydrolyzed to prepare metatitanic acid $\left(\mathrm{H}_{2} \mathrm{TiO}_{3}\right)$ with a suitable particle size $\mathrm{D}(0.5)$ of $1.0-1.5 \mu \mathrm{m}$. The particle size $\mathrm{D}(0.5)$ of the hydrolyzed $\mathrm{H}_{2} \mathrm{TiO}_{3}$ decreased, while the concentration of $\mathrm{Mg}^{2+}$ and $\mathrm{Al}^{3+}$ increased. Finally, under optimal doping and calcination conditions, the rutile content of the prepared sample was $97.0 \%$, and the achromic abilities of TCS and SCX were 1937 and 1.54, respectively.
\end{abstract}

Keywords: Pretreatment of low-grade titanium slag, $\mathrm{NaOH}$ molten salt method, Sulfate process, Hydrolysis with impurity, Rutile $\mathrm{TiO}_{2}$ pigments

\section{Introduction}

Titanium dioxide $\left(\mathrm{TiO}_{2}\right)$ is one of the best known white pigments. It is widely used as filler for paint, plastic, paper, and cosmetics due to its high achromic ability, together with its chemical and heat stability [1]. The traditional commercial technologies for the manufacture of titanium dioxide are the sulfate and chloride processes. In the sulfate process, ilmenite

${ }^{*}$ Corresponding author. $*$ Tel/fax: +86-010-82544847.

Email address:* taoqi@ipe.ac.cn. 
$\left(40-60 \% \mathrm{TiO}_{2}\right)$ and titanium slag $\left(70-80 \% \mathrm{TiO}_{2}\right)$ are used as raw materials. In the chloride process, the raw materials used are rutile (natural or synthetic) and high-grade titanium slag $\left(85-90 \% \mathrm{TiO}_{2}\right)[2]$.

Panzhihua titanomagnetite minerals account for more than $90 \%$ of the titanium reserve in China [3]. At present, titanomagnetite concentrates are smelted in a blast furnace to produce cast iron and titanium slag. The titanium slag contains $22-25 \% \mathrm{TiO}_{2}$ existing as the perovskite structure $\left(\mathrm{CaTiO}_{3}\right)[4,5]$. Due to the stability of the perovskite structure, the refinement of the titanium components is difficult [6]. Thus, in order to fully utilize the Panzhihua abundant titanium resources, the titanomagnetite concentrates were first reduced in a rotary hearth furnace (RHF) by direct reduction-electric furnace smelting, to produce cast iron and titanium slag. The titanium slag contains $42-45 \% \mathrm{TiO}_{2}$ existing as the active anosovite structure $\left(\mathrm{Ti}_{3} \mathrm{O}_{5}\right.$, $\mathrm{FeTi}_{2} \mathrm{O}_{5}$, or $\left.\mathrm{MgTi}_{2} \mathrm{O}_{5}\right)[7,8]$. However, plenty of impurities, such as $\mathrm{Mg}, \mathrm{Al}$, and $\mathrm{Si}$, still exist in the titanium slag. Particularly, the high content of silicon $\left(\mathrm{SiO}_{2} 17-20 \mathrm{wt} . \%\right)$ prevents the acidolysis in $\mathrm{TiO}_{2}$ production by the sulfate process.

Recently, Qi et al [8-11] proposed a $\mathrm{NaOH}$ molten salt decomposition process for the preparation of $\mathrm{TiO}_{2}$, to deal with the low grade titanium slag that is hard to use directly in the sulfate process. In this process, titanium slag $(\sim 75 \mathrm{wt} . \%)$ and high-grade titanium slag ( 90 wt.\%) were decomposed by $\mathrm{NaOH}$ molten salt, forming the intermediate product $\mathrm{Na}_{2} \mathrm{TiO}_{3}$, with a NaCl-type crystal structure [12]. The obtained intermediate sample was washed with water to recycle the $\mathrm{NaOH}$ reaction medium and obtain the layered $\mathrm{H}_{2-\mathrm{x}} \mathrm{Na}_{\mathrm{x}} \mathrm{TiO}_{3}$ intermediate. The obtained $\mathrm{NaOH}$ solution was recycled into the $\mathrm{NaOH}$ molten salt roasting process, after concentration and purification by the removal of $\mathrm{Si}, \mathrm{Al}$, and $\mathrm{Mn}$. The $\mathrm{NaOH}$ molten salt decomposition process can be considered as a mineral activation process, making it suitable for use in the sulfate process for $\mathrm{TiO}_{2}$ production.

Unlike the traditional sulfate process for $\mathrm{TiO}_{2}$ production, the $\mathrm{H}_{2-\mathrm{x}} \mathrm{Na}_{\mathrm{x}} \mathrm{TiO}_{3}$ intermediate can be easily converted into the $\mathrm{TiOSO}_{4}$ solution $\left(\sim 240 \mathrm{~g} / \mathrm{L} \mathrm{TiO} 2\right.$ with $\left.<10 \mathrm{~g} / \mathrm{L} \mathrm{Fe}{ }^{2+}\right)$ at low-temperature and low-acidity in one step [13]. Hydrolysis of the titanyl sulfate solution to prepare the metatitanic acid $\left(\mathrm{H}_{2} \mathrm{TiO}_{3}\right)$ is the essential step of the sulfate process, as the quality of the final $\mathrm{TiO}_{2}$ pigment is directly affected by the properties of $\mathrm{H}_{2} \mathrm{TiO}_{3}$. There are many research studies about the factors that affect the hydrolysis process, such as $\mathrm{TiOSO}_{4}$ 
concentration, free $\mathrm{H}_{2} \mathrm{SO}_{4}$, nuclei, stirrer speed, impurity, heating rate, etc. [14-19]. However, due to the high amount of impurities (especially $\mathrm{Mg}$ and $\mathrm{Al}$ ) contained in the titanyl sulfate solution, low-grade titanium slag needs special consideration with respect to the effect of $\mathrm{Mg}$ and $\mathrm{Al}$ in the hydrolysis process.

After the calcination of $\mathrm{H}_{2} \mathrm{TiO}_{3}$, the $\mathrm{TiO}_{2}$ white pigment can be prepared. In order to improve the pigment performance of the $\mathrm{TiO}_{2}$ white pigment products, the pigments are doped with additives such as $\mathrm{K}, \mathrm{P}$, and $\mathrm{Zn}$ salts, and rutile nuclei [11,20-23]. The $\mathrm{K}$ salt can improve the tinting strength and hiding power, and resist the sintering of titanium dioxide during calcination, but it has an inhibitory effect on the transition of $\mathrm{TiO}_{2}$ from the anatase to the rutile phase. The $\mathrm{Zn}$ salt has the opposite properties of the $\mathrm{K}$ salt. For example, it can induce the anatase-to-rutile phase transition, and the sintering of titanium dioxide particles, at the same time. $\mathrm{P}$ compounds can improve whiteness and make the $\mathrm{TiO}_{2}$ crystals grow into a regular shape. Meanwhile, the rutile nuclei are added with the aim to increase the transition of the rutile, and partially replace the addition of the $\mathrm{Zn}$ salt.

This study focuses on the mineralogical composition of titanium slag, the structural transformation in the alkali pretreatment process, the influence of $\mathrm{Mg}^{2+}$ and $\mathrm{Al}^{3+}$ impurities in the hydrolysis process, and the regulation of $\mathrm{TiO}_{2}$ pigment quality.

\section{Experimental and computational details}

\subsection{Experimental procedure}

An alternative route for the production of $\mathrm{TiO}_{2}$ white pigment by using high-silicon titanium slag was proposed, based on the $\mathrm{NaOH}$ molten salt decomposition process. A brief flow sheet of the novel process is shown in Fig. 1. The key steps are highlighted in yellow and discussed in this paper.

In this process, the titanium slag was first sodiumized and oxidized to invert it into activated titanium intermediate. The obtained intermediate sample was countercurrently washed with water to recycle the $\mathrm{NaOH}$ reaction medium. The washed solid was digested with $40 \%$ sulfuric acid at low temperature. To ensure high recovery of $\mathrm{Ti}$, we employed three-level countercurrent washing after the acidolysis process. A titanyl sulfate solution with high impurity of $\mathrm{Mg}$ and $\mathrm{Al}$ was formed in the subsequent concentration/hydrolysis operation. 
In the hydrolysis process, external-seeds were added to increase the hydrolysis rate and reduce the hydrolysis time. The precipitate $\mathrm{H}_{2} \mathrm{TiO}_{3}$ was then washed to remove soluble impurities and residual acid. Finally, the intermediate product was doped with K, P, Zn, and rutile nuclei, and calcined at the selected temperature to complete crystalline growth.

\subsection{Experimental details}

\subsection{1. $\mathrm{NaOH}$ molten salt roasting process}

The titanium slag used in this work was supported by Panzhihua iron and steel group (Sichuan, PR of China). The detailed chemical composition of the titanium slag was analyzed using inductively coupled plasma optical emission spectroscopy (ICP-OES, Optima 5300DV, Perkin-Elmer, USA), as shown in Table 1. In order to detect the content of $\mathrm{Ti}_{2} \mathrm{O}_{3}$, the titanium slag was first treated with $4.7 \mathrm{vol} \% \mathrm{HCl}$ to remove metallic iron, and then the solid residue was decomposed with $36 \mathrm{wt} . \% \mathrm{HCl}$ in a homogeneous reactor at $130{ }^{\circ} \mathrm{C}$. In the sulfate process the concentration of $\mathrm{Ti}(\mathrm{III})$ can be detected by $\left(\mathrm{NH}_{4}\right) \mathrm{Fe}\left(\mathrm{SO}_{4}\right)_{2}$ standard solution with $\mathrm{NH}_{4} \mathrm{SCN}$ indicator. In this work, we used the same method to determine the concentration of $\mathrm{Ti}(\mathrm{III})$ and the content of $\mathrm{TiO}_{2}$ and $\mathrm{Ti}_{2} \mathrm{O}_{3}$.

Table 1. Chemical compositions of the titanium slag (wt.\%)

\begin{tabular}{ccccccccc}
\hline Component & $\mathrm{TiO}_{2}$ & $\mathrm{Ti}_{2} \mathrm{O}_{3}$ & $\mathrm{MgO}$ & $\mathrm{Al}_{2} \mathrm{O}_{3}$ & $\mathrm{SiO}_{2}$ & $\mathrm{CaO}$ & $\mathrm{MnO}$ & $\sum \mathrm{Fe}$ \\
\hline Content (wt.\%) & 31.13 & 12.56 & 14.36 & 17.55 & 17.77 & 4.49 & 0.9 & 1.24 \\
\hline
\end{tabular}

The mineralogical analysis of the sample was investigated using X-ray diffraction (XRD, X'Pert PRO MPD, PANalytical, Netherlands) performed using $\mathrm{Cu} \mathrm{K} \alpha$ radiation $(\lambda=$ $1.5408 \AA$ A). In order to obtain accurate crystalline information, we used the GSAS-expgui programs [24] to refine the XRD patterns. GSAS (General Structure Analysis System) [25] is a comprehensive system for the refinement of structural models to XRD data. The XRD analysis of the titanium slag (Fig. 2) indicates that the main titanium compositions are the anosovite structure $\left(\mathrm{M}_{3} \mathrm{O}_{5}\right)$ and the spinel structure $\left(\mathrm{M}_{3} \mathrm{O}_{4}\right)$, where the $\mathrm{M}_{3} \mathrm{O}_{4}$ or $\mathrm{M}_{3} \mathrm{O}_{5}$ is a solid solution with $\mathrm{M}$ sites occupied by $\mathrm{Ti}, \mathrm{Mg}, \mathrm{Al}$, or $\mathrm{Fe}$. In order to simplify the crystal structures 
and to easily deal with the XRD refinement program, the structures of $\mathrm{M}_{3} \mathrm{O}_{5}$ and $\mathrm{M}_{3} \mathrm{O}_{4}$ are fixed as $\mathrm{MgTi}_{2} \mathrm{O}_{5}$ and $\mathrm{MgAl}_{2} \mathrm{O}_{4}$, respectively. The structures are shown in Table 2. All the atom sites in the unit cell have been obtained by ABINIT code (version 7.2.1) $[26,27]$ with the GGA (PBE) pseudopotential of the Fritz-Haber-Institute (FHI) [28] provided on the web page of the ABINIT code at http://www.abinit.org. As the atom position is fixed, the values of $\mathrm{R}_{\mathrm{W}}$ and $\mathrm{R}_{\mathrm{wp}}$ (blank) can only be controlled at $5-12 \%$. The mineralogical composition is shown in Fig. 2.

Table 2. Crystal structure optimized by ABINIT code

\begin{tabular}{cccccccccc}
\hline $\begin{array}{c}\text { Chemical } \\
\text { formula }\end{array}$ & $\begin{array}{c}\text { Space } \\
\text { group }\end{array}$ & $\mathrm{Z}$ & $a$ & $b$ & $c$ & $\alpha$ & $\beta$ & $\gamma$ & $\begin{array}{c}\text { Optimized } \\
\text { content }\end{array}$ \\
\hline $\mathrm{MgTi}_{2} \mathrm{O}_{5}$ & $C m c m$ & 4 & 3.765 & 9.777 & 9.957 & 90 & 90 & 90 & geometry \\
$\mathrm{MgAl}_{2} \mathrm{O}_{4}$ & $F d-3 m$ & 8 & 8.117 & 8.117 & 8.117 & 90 & 90 & 90 & geometry \\
$\mathrm{Mg}_{2} \mathrm{SiO}_{4}$ & $P n m a$ & 4 & 4.775 & 10.191 & 5.976 & 90 & 90 & 90 & geometry \\
$\mathrm{Na}_{2} \mathrm{MgSiO}_{4}$ & $P n a 21$ & 4 & 10.916 & 5.288 & 7.056 & 90 & 90 & 90 & geometry \\
$\mathrm{SiO}_{2}$ & $P 3121$ & 3 & 4.913 & 4.913 & 5.405 & 90 & 90 & 120 & energy \\
$\mathrm{Na}_{2} \mathrm{O}$ & $F m-3 m$ & 4 & 5.550 & 5.550 & 5.550 & 90 & 90 & 90 & energy \\
$\mathrm{Na}_{4} \mathrm{SiO}_{4}$ & $P-43 m$ & 1 & 4.885 & 4.885 & 4.885 & 90 & 90 & 90 & unit cell \\
$\mathrm{Na}_{2} \mathrm{SiO}_{3}$ & $C m c 21$ & 4 & 10.480 & 6.070 & 4.820 & 90 & 90 & 90 & geometry \\
$\mathrm{MgO}$ & $F m-3 m$ & 4 & 4.211 & 4.211 & 4.211 & 90 & 90 & 90 & energy \\
\hline
\end{tabular}

Note: The crystal structure of $\mathrm{Na}_{4} \mathrm{SiO}_{4}$ that cannot be indexed from the inorganic crystal structure database (ICSD) is derived from the structure of $\mathrm{Na}_{4} \mathrm{CO}_{4}$ (ICSD \#245406).

The titanium slag was dried, ground, and dry-sieved in order to prepare different narrow size fractions. The titanium slag used in this study was $<74 \mu \mathrm{m}$ (mass percent $>80 \%$ ). The experiments were performed with a muffle furnace and nickel crucibles. $\mathrm{NaOH}$ and titanium slag with a mass ratio of 1.1:1, was placed into the nickel crucibles, and heated in a muffle furnace at different temperatures for $2 \mathrm{~h}$. The temperature of the muffle furnace was controlled using a programmable temperature controller.

The extent of the titanium conversion was calculated by dissolving the intermediate product in 4.7 vol. \% $\mathrm{HCl}$ [29], since the unreacted titanium slag does not dissolve under such low acidity. The concentration of titanium in the filtrate was analyzed by ICP-OES.

\subsubsection{Hydrolysis process}

The typical composition of industrial titanyl sulfate $\left(\mathrm{TiOSO}_{4}\right)$ solution, taken from the sulfate process, was $\mathrm{TiO}_{2}$ of $180-210 \mathrm{~g} / \mathrm{L}, F$ value $=\left(\right.$ effective $\left.\mathrm{H}_{2} \mathrm{SO}_{4}\right) / \mathrm{TiO}_{2}=1.7-2.0$, 
$\mathrm{Fe} / \mathrm{TiO}_{2}=0.25-0.33$ (mass ratio), $\mathrm{Ti}^{3+}$ of about $2.0 \mathrm{~g} / \mathrm{L}$.

In this study, the titanium sulfate $\left(\mathrm{TiOSO}_{4}\right)$ solution, with a high content of $\mathrm{Mg}$ and $\mathrm{Al}$, was obtained by dissolving the acid leaching solid with $40 \mathrm{wt} . \% \mathrm{H}_{2} \mathrm{SO}_{4}$ at $60{ }^{\circ} \mathrm{C}$. The composition is shown in Table 3. The elements of impurity were analyzed using ICP-OES. The concentrations of the total $\mathrm{H}_{2} \mathrm{SO}_{4}$, free $\mathrm{H}_{2} \mathrm{SO}_{4}$, and $\mathrm{TiO}_{2}$ were determined by chemical titration.

The main components of the acid-insoluble substance were $\mathrm{SiO}_{2} \cdot \mathrm{nH}_{2} \mathrm{O}$ colloid, $\mathrm{CaSO}_{4} \cdot 2 \mathrm{H}_{2} \mathrm{O}$, and the undecomposed spinel phase.

Table 3. Chemical compositions of the primary titanium sulfate solution $(\mathrm{g} / \mathrm{L})$

\begin{tabular}{ccccccccccc}
\hline Component & $\mathrm{TH}_{2} \mathrm{SO}_{4}$ & $\mathrm{FH}_{2} \mathrm{SO}_{4}$ & $\mathrm{TiO}_{2}$ & $\mathrm{Na}$ & $\mathrm{Ca}$ & $\mathrm{Mg}$ & $\mathrm{Al}$ & $\mathrm{Si}$ & $\mathrm{Mn}$ & $\mathrm{Fe}$ \\
\hline TiOSO & \\
4
\end{tabular}

Note: $\mathrm{TH}_{2} \mathrm{SO}_{4}$ and $\mathrm{FH}_{2} \mathrm{SO}_{4}$ represent the total and free $\mathrm{H}_{2} \mathrm{SO}_{4}$, respectively. The concentrations of $\mathrm{TiO}_{2}$ were determined by chemical titration and ICP-OES analysis, respectively, and are divided by a slash.

In order to obtain an excellent white pigment property, it is important to prepare $\mathrm{H}_{2} \mathrm{TiO}_{3}$ in a suitable particle size. Thus, the concentration of $\mathrm{TiOSO}_{4}$, as one of the most important factors, was studied in this work. The $\mathrm{TiOSO}_{4}$ solution was concentrated to 120, 150, 160, 170, 180 , and $200 \mathrm{~g} / \mathrm{L}$, respectively. The titanyl sulfate solution was hydrolyzed at boiling temperature $\left(105-107^{\circ} \mathrm{C}\right)$ in a $500-\mathrm{mL}$ four-necked round-bottomed flask at atmospheric pressure.

In order to investigate the effect of $\mathrm{Mg}$ and $\mathrm{Al}, \mathrm{Ti}\left(\mathrm{SO}_{4}\right)_{2}$ with a certain amount of $\mathrm{Al}_{2}\left(\mathrm{SO}_{4}\right)_{3}$ and $\mathrm{MgSO}_{4}$ were dissolved in water to simulate the real system. The simulated system was $\mathrm{TiO}_{2}$ having a concentration of $180 \mathrm{~g} / \mathrm{L}$ and an $F$ value of 1.85 with concentrations of $\mathrm{Mg}$ and Al from $5 \mathrm{~g} / \mathrm{L}$ to $30 \mathrm{~g} / \mathrm{L}$, respectively. Dilute $\mathrm{H}_{2} \mathrm{SO}_{4}$ solutions and $\mathrm{NaOH}$ were used to adjust the $F$ value.

The particle size distribution was measured with a Mastersizer 2000 laser size analyzer (Malvern Instrument Ltd., UK) combined with a Hydro2000MU accessory.

\subsubsection{Doping and calcination}

The metatitanic acid $\left(\mathrm{H}_{2} \mathrm{TiO}_{3}\right)$ cake was washed until most of the impurities were removed, 
and then claimed at $950{ }^{\circ} \mathrm{C}$, to obtain the titanium dioxide product. The chemical composition of the $\mathrm{TiO}_{2}$ product, analyzed by X-ray fluorescence spectrometer (XRF, RIGAKU Simultix 12, Japan), is shown in Table 4. The product could be used as pigment after the doping treatment.

Table 4. The chemical composition of the titanium dioxide after calcination without dopant addition (wt.\%).

\begin{tabular}{cccccccccc}
\hline $\mathrm{TiO}_{2}$ & $\mathrm{SO}_{3}$ & $\mathrm{ZrO}_{2}$ & $\mathrm{Al}_{2} \mathrm{O}_{3}$ & $\mathrm{SiO}_{2}$ & $\mathrm{MgO}$ & $\mathrm{P}_{2} \mathrm{O}_{5}$ & $\mathrm{Fe}_{2} \mathrm{O}_{3}$ & $\mathrm{Na}_{2} \mathrm{O}$ & $\mathrm{K}_{2} \mathrm{O}$ \\
\hline 99.35 & 0.314 & 0.171 & 0.055 & 0.045 & 0.042 & 0.012 & 0.0034 & 0.003 & 0.001 \\
\hline
\end{tabular}

During the experiments, $\mathrm{H}_{2} \mathrm{TiO}_{3}$ suspension containing $30 \mathrm{wt} . \%$ of $\mathrm{TiO}_{2}$ and the dopants $\left(\mathrm{K}_{2} \mathrm{O}, \mathrm{P}_{2} \mathrm{O}_{5}, \mathrm{ZnO}\right.$, and rutile nuclei) were introduced in the form of a solution into the $\mathrm{H}_{2} \mathrm{TiO}_{3}$ suspension. Potassium was doped as $\mathrm{K}_{2} \mathrm{SO}_{4}$, phosphate as $\mathrm{H}_{3} \mathrm{PO}_{4}$, and zinc as $\mathrm{ZnCl}_{2}$. The rutile nuclei were obtained in the sulfate process in an industrial installation. The slurry obtained after thorough mixing (mechanical stirrer $500 \mathrm{~min}^{-1}$ for $20 \mathrm{~min}$ ) was filtered, and then inserted into a laboratory muffle furnace. After calcination, the obtained $\mathrm{TiO}_{2}$ samples were milled in a power-driven agate mortar prior to powder characterization.

The mixture of pigment powder and standard black slurry was pressed into a film having a thickness of $250 \mu \mathrm{m}$. The tristimulus values of $\mathrm{X}, \mathrm{Y}$, and $\mathrm{Z}$ of the film were then measured by an integral ball spectrophotometer (SP60, X-Rite Corporation, USA), contrasting to that of the standard sample R258 (commercial titanium dioxide pigment produced by the sulfate process, Chongqing Titanium Industry Co. Ltd. of Pangang Group). The calculation methods of the reducing power index (TCS) and the blue phase index (SCX) are listed as follow:

$$
\begin{aligned}
& \mathrm{TCS}=\mathrm{TCS}_{\text {standard }}+\left(\mathrm{Y}-\mathrm{Y}_{\text {standard }}\right) \times 100 \\
& \mathrm{SCX}=\mathrm{SCX}_{\text {standard }}+\left(\mathrm{X}_{\text {standard }}-\mathrm{Z}_{\text {standard }}\right)-(\mathrm{X}-\mathrm{Z})
\end{aligned}
$$

The mass fraction of rutile $\left(\mathrm{W}_{\mathrm{R}}\right)$ in the samples was analyzed by Raman spectroscopy (Thermo Scientific DXR, Thermo Fisher, USA).

\section{Results and Discussion}

\subsection{NaOH molten salt decomposition of the titanium slag}

\subsubsection{Effect of temperature and time}

The effect of temperature on the titanium conversion was investigated at a temperature 
range of $450-750{ }^{\circ} \mathrm{C}$ using a $\mathrm{NaOH}$-to-slag mass ratio of 1.1:1. The results in Fig. 3 indicate that the temperature has significant influence on the titanium conversion. The titanium conversion ratio improved with increasing reaction temperatures, especially in the initial stage of the reaction. Temperatures between 550 and $700{ }^{\circ} \mathrm{C}$ had an insignificant effect on the conversion of titanium from titanium slag, and the titanium conversion ratio reached equilibrium within $60 \mathrm{~min}$. When the roasting temperature reached $550{ }^{\circ} \mathrm{C}$ for $60 \mathrm{~min}, 92.2 \%$ titanium conversion was achieved. When the temperature increased to $750{ }^{\circ} \mathrm{C}$, there was an expected increase in the conversion ratio and $\sim 97 \%$ conversion was achieved. However, the product was caking at high-temperatures and needed the high acidity of $\mathrm{H}_{2} \mathrm{SO}_{4}$ to make it dissolve.

\subsubsection{Phase transformation of the high-silicon titanium slag during the NaOH molten salt} roasting process

The results show the presence of $\mathrm{Na}_{2} \mathrm{TiO}_{3}, \mathrm{Na}_{2} \mathrm{MgSiO}_{4}$, and $\mathrm{MgAl}_{2} \mathrm{O}_{4}$ peaks (Fig. 4). It can be considered that the titaniferous solid solutions of the anosovite-type $\left(\mathrm{M}_{3} \mathrm{O}_{5}\right)$ and spinel-type structures $\left(\mathrm{M}_{3} \mathrm{O}_{4}\right)$ are converted to $\mathrm{NaCl}$-type $\mathrm{Na}_{2} \mathrm{TiO}_{3}$. Chen et al. reported the crystal transformation relationship of $\mathrm{Ti}_{3} \mathrm{O}_{5}$ and $\mathrm{Na}_{2} \mathrm{TiO}_{3}[30]$.

There is an overlap between the $\mathrm{Na}_{2} \mathrm{MgSiO}_{4}$ and $\mathrm{NaAlO}_{2}$ peaks. Thus, to distinguish these two crystalline phases, the simulated XRD pattern is shown in the top left corner. As shown in Fig. 4, the main phases are $\mathrm{Na}_{2} \mathrm{TiO}_{3}(45.91 \%)$ and $\mathrm{Na}_{2} \mathrm{MgSiO}_{4}(28.46 \%)$ after the $\mathrm{NaOH}$ molten salt was pretreated.

In this paper, we focus on the investigation of the crystal transformation relationship of $\mathrm{Mg}_{2} \mathrm{SiO}_{4}$ and $\mathrm{Na}_{2} \mathrm{MgSiO}_{4}$. It is reported that the chemical reaction between $\mathrm{Mg}_{2} \mathrm{SiO}_{4}$ and $\mathrm{Na}_{2} \mathrm{MgSiO}_{4}$ can be described as follows [31]:

$$
\begin{aligned}
& \mathrm{Mg}_{2} \mathrm{SiO}_{4}+2 \mathrm{NaOH} \rightarrow \mathrm{Na}_{2} \mathrm{MgSiO}_{4}+\mathrm{MgO}+\mathrm{H}_{2} \mathrm{O} \\
& \mathrm{Na}_{2} \mathrm{MgSiO}_{4}+2 \mathrm{NaOH} \rightarrow \mathrm{Na}_{4} \mathrm{SiO}_{4}+\mathrm{MgO}+\mathrm{H}_{2} \mathrm{O}
\end{aligned}
$$

It is considered that $\mathrm{Mg}_{2} \mathrm{SiO}_{4}$ will invert into $\mathrm{Na}_{4} \mathrm{SiO}_{4}$ when $\mathrm{NaOH}$ is in great excess. However, the crystal structure of $\mathrm{MgO}$ does not exist in the XRD pattern. To explain the formation of the $\mathrm{Na}_{2} \mathrm{MgSiO}_{4}$ product without $\mathrm{MgO}$ being also formed, the energy change $(\Delta \mathrm{E})$ between is calculated by using the ABINIT code shown, as follows: 


$$
\begin{array}{ll}
\mathrm{SiO}_{2}+\mathrm{Na}_{2} \mathrm{O} \rightarrow \mathrm{Na}_{2} \mathrm{SiO}_{3} & \Delta \mathrm{E}=-232.424 \mathrm{~kJ} / \mathrm{mol} \\
\mathrm{Mg}_{2} \mathrm{SiO}_{4}+\mathrm{Na}_{2} \mathrm{O} \rightarrow \mathrm{Na}_{2} \mathrm{MgSiO}_{4}+\mathrm{MgO} & \Delta \mathrm{E}=-165.024 \mathrm{~kJ} / \mathrm{mol} \\
\mathrm{MgO}+\mathrm{Na}_{2} \mathrm{SiO}_{3} \rightarrow \mathrm{Na}_{2} \mathrm{MgSiO}_{4} & \Delta \mathrm{E}=-7.258 \mathrm{~kJ} / \mathrm{mol} \\
\mathrm{SiO}_{2}+2 \mathrm{Na}_{2} \mathrm{O} \rightarrow \mathrm{Na}_{4} \mathrm{SiO}_{4} & \Delta \mathrm{E}=-98.097 \mathrm{~kJ} / \mathrm{mol} \\
1 / 2 \mathrm{Mg}_{2} \mathrm{SiO}_{4}+1 / 2 \mathrm{Na}_{4} \mathrm{SiO}_{4} \rightarrow \mathrm{Na}_{2} \mathrm{MgSiO}_{4} & \Delta \mathrm{E}=-153.304 \mathrm{~kJ} / \mathrm{mol} \\
1 / 2 \mathrm{SiO}_{2}+\mathrm{Na}_{2} \mathrm{O}+1 / 2 \mathrm{Mg}_{2} \mathrm{SiO}_{4} \rightarrow \mathrm{Na}_{2} \mathrm{MgSiO}_{4} & \Delta \mathrm{E}=-202.353 \mathrm{~kJ} / \mathrm{mol}
\end{array}
$$

From the energy changes of these six chemical reaction equations, Eq. (3) and (8) seem to show more activity. It can be considered that in Eq. (3) the surface of quartz $\mathrm{SiO}_{2}$ reacts with $\mathrm{O}^{2-}$ in a nucleophilic addition and a $\mathrm{SiO}_{3}{ }^{2-}$ group is formed. Structurally, the crystal structure of $\mathrm{Mg}_{2} \mathrm{SiO}_{4}$, with a Pnma space group, has two types of $\mathrm{Mg}^{2+}$ ions that are located at different sites in the unit cell. One is connected with the $\mathrm{SiO}_{4}$ tetrahedron structure and exists in a layered $\left[\mathrm{MgSiO}_{4}\right]^{2-}$ group, the other is inserted in the interlayer and has a high activate energy. Comparing with the $\left[\mathrm{MgSiO}_{4}\right]^{2-}$ group from $\mathrm{Mg}_{2} \mathrm{SiO}_{4}$, the crystal structure of $\mathrm{Na}_{2} \mathrm{MgSiO}_{4}$, with a space group Pna21, has a similar $\left[\mathrm{MgSiO}_{4}\right]^{2-}$ group. We concluded that the activated $\mathrm{Mg}^{2+}$ ion exchanged by a $\mathrm{Na}^{+}$ion keeps the layered $\left[\mathrm{MgSiO}_{4}\right]^{2-}$ structure at the low activation energy in Eq. (4). After the ion exchange reaction, the fresh $\mathrm{Mg}^{2+}$ and $\mathrm{SiO}_{3}{ }^{2-}$ are combined with $\mathrm{O}^{2-}$ and the stable $\left[\mathrm{MgSiO}_{4}\right]^{2-}$ structure is formed. Therefore, the existence of $\mathrm{SiO}_{3}{ }^{2-}$ and $\mathrm{O}^{2-}$ inhibits the generation of $\mathrm{MgO}$. This is consistent with the calculated results between Eq. (4) and (8).

\subsubsection{The chemical equation of titanium slag with $\mathrm{NaOH}$ molten salt}

The reaction of high-grade titanium slag (main component $\mathrm{Ti}_{3} \mathrm{O}_{5}$ ) with the alkali system yields $\mathrm{Na}_{2} \mathrm{TiO}_{3}$ and this can be described as follows, according to the high-grade titanium result [9]:

$$
2 \mathrm{Ti}_{3} \mathrm{O}_{5}+12 \mathrm{NaOH}+\mathrm{O}_{2}(\mathrm{~g}) \rightarrow 6 \mathrm{Na}_{2} \mathrm{TiO}_{3}+6 \mathrm{H}_{2} \mathrm{O}(\mathrm{g})
$$

If $1 \mathrm{~mol}$ of Ti is fixed as 1 unit, the ICP-OES result of high-silicon titanium slag in Table 1 can be rewritten as shown in the second line in Table 5. The mol of $\mathrm{Na}$ is calculated with a $\mathrm{NaOH}$ and titanium slag mass ratio of 1.1:1. In the third line, the component of the raw material is obtained from the result of the XRD refinement, and the anosovite-type $\left(\mathrm{M}_{3} \mathrm{O}_{5}\right)$ and spinel-type structures $\left(\mathrm{M}_{3} \mathrm{O}_{4}\right)$ are simplified as $\mathrm{MgTi}_{2} \mathrm{O}_{5}$ and $\mathrm{MgAl}_{2} \mathrm{O}_{4}$, respectively. Therefore, the contents of the titanium slag obtained by XRD are different from those 
obtained by ICP-OES. In the fourth line, the component of the product is obtained from the result of the XRD refinement. Because the crystal structures of $\mathrm{Na}_{2} \mathrm{TiO}_{3}, \mathrm{Na}_{2} \mathrm{MgSiO}_{4}$, and $\mathrm{NaAlO}_{2}$ are not solid solutions, and the solid solution $\mathrm{M}_{3} \mathrm{O}_{4}$ (simplified as $\mathrm{MgAl}_{2} \mathrm{O}_{4}$ ) is only $4.64 \mathrm{wt} . \%$, the components of the product obtained by XRD refinement are very close to the ICP-OES result. For example, the $\mathrm{Si}(0.525$ units) and $\mathrm{Mg}$ (0.637 units) of the reactant (ICP-OES) are close to the $\mathrm{Si}$ (0.543 units) and $\mathrm{Mg}$ (0.645 units) of the product (XRD). By comparison with the content of $\mathrm{Na}$, we conclude that the $\mathrm{NaOH}$ excess is $25.8 \%$.

Table 5. The compositions of the titanium slag (molar ratio) obtained from ICP-OES and XRD refinement

\begin{tabular}{ccccccc}
\hline Component (molar ratio) & $\mathrm{Na}$ & $\mathrm{Ti}(\mathrm{IV})$ & $\mathrm{Ti}(\mathrm{III})$ & $\mathrm{Mg}$ & $\mathrm{Al}$ & $\mathrm{Si}$ \\
\hline Reactant (ICP+ chemical titration) & 4.879 & 0.690 & 0.310 & 0.637 & 0.611 & 0.525 \\
Titanium slag (XRD) & -- & 1 & -- & 1.467 & 0.630 & 0.603 \\
Product (XRD) & 3.879 & 1 & -- & 0.645 & 0.994 & 0.543 \\
\hline
\end{tabular}

${ }^{a}$ Note: The amount of Ti was set as 1 unit

According to the XRD and ICP results, the reaction of low-grade titanium should be described as follows:

$$
\begin{aligned}
& 0.829 \mathrm{Mg}_{\mathrm{x}} \mathrm{Al}_{\mathrm{y}} \mathrm{Ti}_{3-\mathrm{x}-\mathrm{y}} \mathrm{O}_{5} \text { (anosovite) }+0.520 \mathrm{Mg}_{\mathrm{m}} \mathrm{Al}_{\mathrm{n}} \mathrm{Ti}_{3-\mathrm{m}-\mathrm{n}} \mathrm{O}_{4} \text { (spinel) }+0.541 \mathrm{Mg}_{2} \mathrm{SiO}_{4}+ \\
& 0.459 \mathrm{SiO}_{2}+7.138 \mathrm{NaOH}+0.151 \mathrm{O}_{2}(\mathrm{~g}) \rightarrow 1.840 \mathrm{Na}_{2} \mathrm{TiO}_{3}+\mathrm{Na}_{2} \mathrm{MgSiO}_{4}+1.457 \mathrm{NaAlO}_{2}+ \\
& 0.186 \mathrm{Mg}_{\mathrm{i}} \mathrm{Al}_{\mathrm{j}} \mathrm{Ti}_{3-\mathrm{i}-\mathrm{j}} \mathrm{O}_{4} \text { (spinel) }+3.569 \mathrm{H}_{2} \mathrm{O}(\mathrm{g})
\end{aligned}
$$

From Eq. (10), Ti(III) is oxidized by $\mathrm{O}_{2}$ and converted into Ti(IV). Abstract Eq. (11) is listed to obtain the content of $\mathrm{Ti}(\mathrm{III})$ that is about $32.8 \%$ of the component of Ti. This result is very close to the chemical titration result of $31.0 \%$.

$$
0.604 \mathrm{Ti}^{3+}+0.151 \mathrm{O}_{2} \rightarrow 0.604 \mathrm{Ti}^{4+}+0.302 \mathrm{O}^{2-} \quad\left(\sum \mathrm{Ti}=1.840 \text { units }\right)
$$

Based on the conclusion that the excess $\mathrm{NaOH}$ is about $25.8 \%$, the $\mathrm{NaOH}$-to-slag mass ratio of 0.9:1 should exactly meet the stoichiometric ratio. In order to reduce the addition of $\mathrm{NaOH}$, mass ratios of $0.9: 1,1.0: 1$, and 1.1:1 were adopted to investigate the influence of $\mathrm{NaOH}$-to-slag mass ratio on titanium conversion at $550{ }^{\circ} \mathrm{C}$. The results in Fig. 4 show that the titanium conversion ratio improves with an increase in the $\mathrm{NaOH}$-to-slag mass ratio. Therefore, excess sodium hydroxide was necessary to maintain the liquidity of the reactants and to ensure that sufficient reaction took place. 
However, this result is quite different with titanium-enriched slag $(\sim 75 \mathrm{wt} . \%)$ and high-grade titanium slag ( $90 \mathrm{wt} . \%)$. For these two kinds of slag, the titanium conversion ratio reached a minimum of $80 \%$ within $10 \mathrm{~min}$ at $550{ }^{\circ} \mathrm{C}[9,32]$, while in this work, the conversion ratio is only about $60 \%$. We concluded that the high content of spinel-type $\mathrm{M}_{3} \mathrm{O}_{4}$ solid solution should be the main reason for this difference, since both the titanium-enriched slag and the high-grade titanium slag only have one mineral phase of anosovite. Wang et.al [10] considered that initially, the reaction is a chemical reaction controlled process, or a diffusion through the liquid boundary layer controlled process. As the reaction proceeds, it may be controlled by diffusion through the residue layer. In this system we concluded that the influence of the content of Ti(III) is a very important factor. Since the bond length of $\mathrm{Ti}(\mathrm{III})-\mathrm{O}(2.0-2.2 \AA)$ is longer than that of $\mathrm{Ti}(\mathrm{IV})-\mathrm{O}(1.9-2.0 \AA)$, it should be easily broken by $\mathrm{O}^{2-}$ to form new Ti-O ligands. Moreover, the influence of the content of $\mathrm{M}_{3} \mathrm{O}_{5}$ solid solution is another important factor, as $\mathrm{M}_{3} \mathrm{O}_{5}$ exhibits an anosovite structure that has an open-framework along the $\left[\begin{array}{lll}0 & 0 & 1\end{array}\right]$ direction. The $\mathrm{O}^{2-}$ anions can diffuse along the $\left[\begin{array}{lll}0 & 0 & 1\end{array}\right]$ direction. This is beneficial for this nucleophilic reaction. Thus, the reaction rate of $\mathrm{M}_{3} \mathrm{O}_{5}$ should be faster than that of the spinel-type $\mathrm{M}_{3} \mathrm{O}_{4}$ solid solution.

\subsection{Hydrolysis with high impurity of $M g, A l$}

After concentrating the prime $\mathrm{TiOSO}_{4}$ solution, the hydrolysis process was conducted at $150,160,170,180$, and $200 \mathrm{~g} / \mathrm{L}$ concentrations of $\mathrm{TiO}_{2}$, and a selected $F$ value of about 1.85 . As expected, the average particle size of the meta-titanic acid samples decreased as the concentration of $\mathrm{TiO}_{2}$ increased as shown in Fig. 6. It is well known that a higher concentration of $\mathrm{TiO}_{2}$ with a higher acidity would inhibit the hydrolysis rate, decrease the initial hydrolysis nuclei number, and increase its radius. This would lead to a decrease in the second nucleation radius, thus eventually improving its pigment properties. According to the industrial sulfate process, a particle size of $1.384 \mu \mathrm{m}$ for $\mathrm{H}_{2} \mathrm{TiO}_{3}$, with a narrow particle size distribution, was beneficial to improve the pigment properties. For the experimental $\mathrm{TiOSO}_{4}$ solution obtained from the titanium slag, the best concentration of $\mathrm{TiO}_{2}$ was $180 \mathrm{~g} / \mathrm{L}$. Comparing this with the pure $\mathrm{Ti}\left(\mathrm{SO}_{4}\right)_{2}$ solution, the concentration of $\mathrm{TiO}_{2}$ is required to be at least $230 \mathrm{~g} / \mathrm{L}$ [33] to obtain a similar particle size. We consider that the $\mathrm{Mg}^{2+}$ and $\mathrm{Al}^{3+}$ ions 
play an important role in the hydrolysis process.

Under the same $\mathrm{TiO}_{2} F$ value and concentration, a series of $\mathrm{TiOSO}_{4}$ solutions were prepared with different concentrations of $\mathrm{Mg}^{2+}$ and $\mathrm{Al}^{3+}$. The particle sizes of $\mathrm{H}_{2} \mathrm{TiO}_{3}$ obtained by hydrolysis are shown in Fig. 7. Both the $\mathrm{Mg}^{2+}$ and $\mathrm{Al}^{3+}$ exhibit predicted effects on the particle size distribution of $\mathrm{H}_{2} \mathrm{TiO}_{3}$. On increasing the concentration of $\mathrm{Mg}^{2+}$, the particle size $\mathrm{D}(0.5)$ of $\mathrm{H}_{2} \mathrm{TiO}_{3}$ is reduced from $6.059 \mu \mathrm{m}$ for $\mathrm{Mg}^{2+}=0$ to $0.993 \mu \mathrm{m}$ for $\mathrm{Mg}^{2+}=30 \mathrm{~g} / \mathrm{L}$. Compared with the addition of $\mathrm{Mg}^{2+}$, the addition of $\mathrm{Al}^{3+}$ had a similar result. We concluded that the positive charges $\left(\mathrm{Mg}^{2+}, \mathrm{Al}^{3+}\right.$, and $\left.\mathrm{H}^{+}\right)$adsorbed on the surface, hinders the onset of coalescence and aggregation, resulting in smaller sizes of the $\mathrm{H}_{2} \mathrm{TiO}_{3}$ aggregates. Secondly, the addition of $\mathrm{Mg}$ and $\mathrm{Al}$ salts enhances the viscosity of the $\mathrm{TiOSO}_{4}$ solution. This negatively affects the collision of the particles, resulting in smaller aggregates.

\subsection{Doping and calcination}

After doping and calcination of metatitanic acid, the uncoated pigments contain $\geq 98 \%$ titanium dioxide. As shown in Table 4, the sample prepared in this work meets commercial requirements. It is clear that minor residues of $\mathrm{Mg}, \mathrm{Al}$, and $\mathrm{Si}$ existing in the product do not affect the pigment properties. We can prepare a suitable $\mathrm{TiO}_{2}$ pigment by adding an appropriate doping agent. The dopant addition can be seen in Table 6. The TCS of sample 10 is about 1937 and is close to that of R258.

Due to the smaller microcrystal formation of $\mathrm{H}_{2} \mathrm{TiO}_{3}$ in this work, the sample is easier to sinter and requires further addition of $\mathrm{K}^{+}$. As shown in Table 6, the addition of $\mathrm{K}^{+}$(samples 1-3) and $\mathrm{PO}_{4}{ }^{3-}$ (samples 4-6) significantly improved the achromic ability, but inhibited the transition from anatase to rutile. In order to improve the conversion of rutile, both the $\mathrm{Zn}^{2+}$ and rutile nuclei were added into the system. As shown in Table 6, the addition of $\mathrm{Zn}^{2+}$ seems to have a more remarkable effect (samples 1-3 compared with samples 10-12) than that of rutile nuclei.

The content of the rutile and the sample size distribution can strongly affect the TCS. It is well-known that the TCS of commercial rutile and anatase $\mathrm{TiO}_{2}$ is about 1700 and 1250 , respectively. Therefore, the rutile content plays the most important role in pigment properties. Another important factor is the particle size distribution of $\mathrm{TiO}_{2}$. The optimum particle size of 
$\mathrm{TiO}_{2}$ pigment is between $0.2-0.3 \mu \mathrm{m}$ (half of the visible wavelength). Unfortunately, it is very difficult to control such a small particle size at the rutile transition temperature. Thus, the content of rutile should be controlled between 96.3 to $97.1 \mathrm{wt} \%$ to obtain optimal pigment properties.

Table 6. Dopant addition and pigment properties for $\mathrm{TiO}_{2}$

\begin{tabular}{|c|c|c|c|c|c|c|c|c|c|}
\hline \multirow{2}{*}{ sample } & \multicolumn{4}{|c|}{ Dopant addition (wt.\%) } & \multirow{2}{*}{ Temperature $/{ }^{\circ} \mathrm{C}$} & \multirow{2}{*}{ Time/min } & \multicolumn{3}{|c|}{ Achromic ability index } \\
\hline & $\mathrm{K}_{2} \mathrm{O}$ & $\mathrm{P}_{2} \mathrm{O}_{5}$ & $\mathrm{ZnO}$ & Rutile nuclei & & & Rutile/wt.\% & TCS & SCX \\
\hline 1 & 0.5 & 0.1 & 0.15 & 5 & 890 & 120 & 99.3 & 1760 & 0.15 \\
\hline 2 & 0.6 & 0.1 & 0.15 & 5 & 890 & 120 & 97.3 & 1770 & 0.51 \\
\hline 3 & 0.7 & 0.1 & 0.15 & 5 & 890 & 120 & 96.35 & 1821 & 0.91 \\
\hline 4 & 0.6 & 0.1 & -- & 6 & 930 & 30 & 100.00 & 1706 & 0.42 \\
\hline 5 & 0.6 & 0.15 & -- & 6 & 930 & 30 & 98.88 & 1718 & 0.39 \\
\hline 6 & 0.6 & 0.2 & -- & 6 & 930 & 30 & 94.49 & 1735 & 1.14 \\
\hline 7 & 0.5 & 0.15 & -- & 6 & 900 & 90 & 99.07 & 1751 & 1.05 \\
\hline 8 & 0.6 & 0.15 & -- & 6 & 900 & 90 & 97.44 & 1777 & 0.98 \\
\hline 9 & 0.7 & 0.15 & -- & 6 & 900 & 90 & 96.89 & 1802 & 0.95 \\
\hline 10 & 0.5 & 0.15 & 0.1 & 6.5 & 900 & 60 & 97.07 & 1937 & 1.54 \\
\hline 11 & 0.6 & 0.15 & 0.1 & 6.5 & 900 & 60 & 96.00 & 1807 & 1.20 \\
\hline 12 & 0.7 & 0.15 & 0.1 & 6.5 & 900 & 60 & 94.49 & 1725 & 1.25 \\
\hline R258 & & & & & & & 97.22 & 1940 & 4.20 \\
\hline
\end{tabular}

Table 7 gives the chemical composition of sample 10. This exhibits the best pigment properties. Before addition of $\mathrm{K}, \mathrm{P}$, and $\mathrm{Zn}, \mathrm{Fe}$ impurities need to be removed from the mixed slurry of $\mathrm{H}_{2} \mathrm{TiO}_{3}$ and rutile nuclei. Therefore, the mixed slurry is washed using $10 \% \mathrm{H}_{2} \mathrm{SO}_{4}$ and Ti(III) solution. As shown in Table 7, the main impurities in sample 10 were $\mathrm{ZrO}_{2}, \mathrm{SiO}_{2}$, and $\mathrm{SO}_{3}$, while the $\mathrm{Mg}, \mathrm{Al}$, and $\mathrm{Fe}$ impurities (shown in Table 4) were completely removed. The dopant contents $\mathrm{K}_{2} \mathrm{O}, \mathrm{P}_{2} \mathrm{O}_{5}$, and $\mathrm{ZnO}$ were $0.185 \%, 0.160 \%$, and $0.03 \%$, respectively.

Table 7. The chemical composition of the sample 10 (wt.\%).

\begin{tabular}{cccccccc}
\hline $\mathrm{TiO}_{2}$ & $\mathrm{ZrO}_{2}$ & $\mathrm{~K}_{2} \mathrm{O}$ & $\mathrm{P}_{2} \mathrm{O}_{5}$ & $\mathrm{SO}_{3}$ & $\mathrm{SiO}_{2}$ & $\mathrm{ZnO}$ & $\mathrm{Na}_{2} \mathrm{O}$ \\
\hline 99.29 & 0.186 & 0.185 & 0.160 & 0.091 & 0.058 & 0.030 & 0.005 \\
\hline
\end{tabular}

\section{Conclusion}

Based on the $\mathrm{NaOH}$ pretreatment of titanium slag, acidolysis of pretreated low-grade titanium slag, hydrolysis of $\mathrm{TiOSO}_{4}$ solution, and doping and calcination of meta-titanic acid, rutile $\mathrm{TiO}_{2}$ white pigment with good pigment properties was prepared from low-grade 
titanium slag.

In the $\mathrm{NaOH}$ molten salt pretreatment process, using a temperature of $550{ }^{\circ} \mathrm{C}$, an alkali-to-titanium slag ratio of $1.1: 1$, and a reaction time of $90 \mathrm{~min}$, a titanium conversion ratio $>92.2 \%$ was achieved, and the main phase of $\mathrm{Ti}_{3} \mathrm{O}_{5}$ and $\mathrm{Mg}_{2} \mathrm{SiO}_{4}$ transformed to $\mathrm{Na}_{2} \mathrm{TiO}_{3}$ and $\mathrm{Na}_{2} \mathrm{MgSiO}_{4}$, respectively. By using DFT calculations and XRD refinement, the crystal structures and the mass content of the indexed mineral phases from XRD patterns were optimized. Based on these results, and the mass content of elements from ICP-OES, the chemical equation of titanium slag with $\mathrm{NaOH}$ molten salt could be described as follows: $0.829 \mathrm{Mg}_{\mathrm{x}} \mathrm{Al}_{\mathrm{y}} \mathrm{Ti}_{3-\mathrm{x}-\mathrm{y}} \mathrm{O}_{5}$ (anosovite) $+0.520 \mathrm{Mg}_{\mathrm{m}} \mathrm{Al}_{\mathrm{n}} \mathrm{Ti}_{3-\mathrm{m}-\mathrm{n}} \mathrm{O}_{4}$ (spinel) $+0.541 \mathrm{Mg}_{2} \mathrm{SiO}_{4}+$ $0.459 \mathrm{SiO}_{2}+7.138 \mathrm{NaOH}+0.151 \mathrm{O}_{2}(\mathrm{~g}) \rightarrow 1.840 \mathrm{Na}_{2} \mathrm{TiO}_{3}+\mathrm{Na}_{2} \mathrm{MgSiO}_{4}+1.457 \mathrm{NaAlO}_{2}+$ $0.186 \mathrm{Mg}_{\mathrm{i}} \mathrm{Al}_{\mathrm{j}} \mathrm{Ti}_{3-\mathrm{i}-\mathrm{j}} \mathrm{O}_{4}($ spinel $)+3.569 \mathrm{H}_{2} \mathrm{O}(\mathrm{g})$

In the hydrolysis process, $\mathrm{H}_{2} \mathrm{TiO}_{3}$ was prepared through the selected condition of $\mathrm{C}_{\mathrm{TiO} 2}=180 \mathrm{~g} / \mathrm{L}$ with a high content of $\mathrm{Mg}^{2+}$ and $\mathrm{Al}^{3+}$. The increase in $\mathrm{Mg}^{2+}$ and $\mathrm{Al}^{3+}$ ions in the titanyl sulfate solution could clearly reduce the particle size of $\mathrm{H}_{2} \mathrm{TiO}_{3}$. It was very beneficial for realizing the hydrolysis with unenriched titanyl sulfate solution.

In the doping and calcination processes, the $\mathrm{TiO}_{2}$ rutile white pigment was prepared by doping $\mathrm{K}_{2} \mathrm{O}$ (0.5 wt.\%), $\mathrm{P}_{2} \mathrm{O}_{5}(0.15$ wt.\%), $\mathrm{ZnO}$ (0.1 wt.\%), and rutile nuclei (6.5 wt.\%), followed by calcination under $900{ }^{\circ} \mathrm{C}$ for $60 \mathrm{~min}$. With this optimization of the preparation conditions, a TCS of 1937 and an SCX of 1.54 approached the commercial pigment standards of R258. The anatase-rutile phase transformation was enhanced by the addition of rutile nuclei and $\mathrm{Zn}$, but inhibited by the addition of $\mathrm{K}$ and $\mathrm{P}$. A 96.3-97.1\% rutile content of $\mathrm{TiO}_{2}$ produced the best pigment properties.

\section{Acknowledgements}

The authors gratefully acknowledge support from the projects endorsed by the Major Program of the National Natural Science Foundation of China (Grant No. 51090380), the Major state Basic Research Development Program of China (Grant No. 2013CB632604), the

National Science Foundation for Distinguished Young Scholars of China (Grant No. 51125018), and the National Natural Science Foundation of China (Grant No. 51402303, 51104139, 51004091, 21006115). 


\section{References}

[1] Tioxide Group Limited. Manufacture and general properties of titanium dioxide pigments. London:Tioxide Ltd;1992.

[2] Zhang W, Zhu ZW, Cheng, CY. A literature review of titanium metallurgical processes Hydrometallurgy, 2011;108:177-88.

[3] Qiu GZ, Jiang T, Xu JC. Direct reduction of cold-bonded pellets. Changsha:Central South University Press;2001.

[4] Zhang L, Zhang LN, Wang MY. Recovery of titanium compounds from molten Ti-bearing blast furnace slag under the dynamic oxidation condition. Miner Eng 2007;20:684-93.

[5] Li LS, Sui ZT. Physical chemistry behavior of enrichment the selectivity of $\mathrm{TiO}_{2}$ in perovskite. Acta Phys Chem Sin 2001;17:845-9.

[6] Wang YB, Qi T, Chu JL, Zhao W. Production of $\mathrm{TiO}_{2}$ from $\mathrm{CaTiO}_{3}$ by alkaline roasting method. Rare Metals 2010;29(2):162-7.

[7] Yuan ZF, Pan YF, Zhou E, Cong XU, Li SQ. Comprehensive utilization of complex titania ore. J Iron Steel Res Int 2007;4(1):1-6.

[8] Chen DS, Song B, Wang LN, Qi T, Wang Y, Wang WJ. Solid state reduction of Panzhihua titanomagnetite concentrates with pulverized coal. Miner Eng 2011;24:864-9.

[9] Xue TY, Wang LN, Qi T, Chu JL, Qu JK, Liu CH. Decomposition kinetics of titanium slag in sodium hydroxide system. Hydrometallurgy 2009;95:22-7.

[10] Wang D, Chu JL, Liu YH, Li J, Xue TY, Wang WJ, Qi T. Novel Process for Titanium Dioxide Production from Titanium Slag: NaOH-KOH Binary Molten Salt Roasting and Water Leaching. Ind Eng Chem Res 2013;52(45):15756-62.

[11] Wang Y, Li J, Wang L, Xue TY, Qi T. Preparation of Rutile Titanium Dioxide White Pigment via Doping and Calcination of Metatitanic Acid Obtained by the $\mathrm{NaOH}$ Molten Salt Method. Ind Eng Chem Res 2010;49:7693-6.

[12] Liu YH, Zhao W, Wang WJ, Yang X, Chu JL. Study on the transformation from $\mathrm{NaCl}$-type $\mathrm{Na}_{2} \mathrm{TiO}_{3}$ to layered titanate. J Phys Chem Solids 2012;73:402-6.

[13] Wang WJ, Xue TY, Wang D, Qi T. Kinetic study on sulfuric acid dissolution of $\mathrm{Na}_{x} \mathrm{H}_{2-\mathrm{x}} \mathrm{TiO}_{3}$ from sodium hydroxide molten method. Adv Mater Res 2014;881-3:1545-8. 
[14] Wang WJ, Liu YH, Xue TY, Li J, Chen DS, Qi T. Mechanism and kinetics of titanium hydrolysis in concentrated titanyl sulfate solution based on infrared and Raman spectra. Chem Eng Sci 2015;134(29):196-204

[15] Tian CX, Du JQ, Chen XH, et al. Influence of hydrolysis in sulfate process on titania pigment producing. Transactions of Nonferrous Metals Society of China 2009;19:829-33.

[16] Tian CX, Huang SH, Ying Y. Anatase $\mathrm{TiO}_{2}$ white pigment production from unenriched industrial titanyl sulfate solution via short sulfate process. Dyes Pigments 2013;96:609-13.

[17] Grzmil B, Grela D, Kic B. Effects of processing parameters on hydrolysis of $\mathrm{TiOSO}_{4}$. Pol J Chem Tech 2009;11(3):15-21.

[18] Grzmil B, Grela D, Kic B. Hydrolysis of titanium sulphate compounds. Chemical Papers 2008;62(1):18-25.

[19] Grzmil B, Grela D, Kic B, Podsiadly M. The influence of admixtures on the course of hydrolysis of titanyl sulfate. Pol J Chem Tech 2008;10(3):4-12.

[20] Grzmil B, Rabe M, Kic B, Lubkowski B. Influence of phosphate, potassium, lithium, and aluminium on the antase-rutile phase transformation. Ind Eng Chem Res 2007;46:1018-24.

[21] Gesenhues, U. Calcination of metatitanic acid to titanium dioxide white pigments. Chem Eng Technol 2001;24:685-94.

[22] Ratajska H. The effect of certain promoters on $\mathrm{TiO}_{2}$ crystal structure transformation. J Therm Anal 1992;38:2109-14.

[23] Karvinen S. The effects of trace elements on the crystal properties of $\mathrm{TiO}_{2}$. Solid State Sci 2003;5:811-9.

[24] Toby BH, EXPGUI, a graphical user interface for GSAS. J Appl Cryst 2001;34: 210-3.

[25] Allen CL, Robert VD. General Structure Analysis System (GSAS), Los Alamos National Laboratory Report LAUR 1994:86-748.

[26] Gonze X, Amadon B, Anglade PM, Beuken JM, Bottin F, Boulanger P, Bruneval F, Caliste D, Caracas R, Cote M, Deutsch T, Genovese L, Ghosez P, Giantomassi M, Goedecker S, Hamann D, Hermet P, Jollet F, Jomard G, Leroux S, Mancini M, Mazevet S, Oliveira MJT, Onida G, Pouillon Y, Rangel T, Rignanese GM, Sangalli D, Shaltaf R, Torrent M, Verstraete MJ, Zérah G, Zwanziger JW. ABINIT: First-principles approach to material and nanosystem properties. Computer Physics Communications 2009;180:2582-615. 
[27] Gonze X, Beuken JM, Caracas R, Detraux F, Fuchs M, Rignanese GM, Sindic L, Verstraete M, Zerah G, Jollet F, Torrent M, Roy A, Mikami M, Ghosez P. Raty JY, Allan DC. First-principles computation of material properties: the ABINIT software project. Comp Mater Sci 2002;25:478-92.

[28] Fuchs M, Scheffler M. Ab initio pseudopotentials for electronic structure calculations of poly-atomic systems using density-functional theory. Comput Phys Commun 1999;119:67-98 [29] Feng Y, Wang JG, Wang LN, Qi T, Xue TY, Chu JL. Decomposition of acid dissolved titanium slag from Australia by sodium hydroxide. Rare Metals 2009;28(6):564-9.

[30] Chen DS, Zhao LS, Liu YH, Qi T, Wang JC, Wang LN. A novel process for recovery of iron, titanium, and vanadium from titanomagnetite concentrates: $\mathrm{NaOH}$ molten salt roasting and water leaching processes. J Hazard Mater 2013;244-5:588-95.

[31] Xu M, Xu Q, Liu RQ, Wang ZR, Zhai YC. Reaction mechanisms of decomposition of magnesium nickel silicate by alkali fusion using $\mathrm{NaOH}$. Chin J Nonferrous Met 2012;22(4):1248-54.

[32] Wang D, Chu JL, Li J, Qi T, Wang WJ. Anti-caking in the process of produce Titanium Dioxide via using low-grade titanium slag by the $\mathrm{NaOH}$ Molten Salt method. Powder Technol 2012;232:99-105

[33] Wang WJ, Chen DS, Chu JL, Li J, Xue TY, Wang LN, Wang D, Qi T. Influence and hydrolysis kinetics in titanyl sulfate solution from the sodium hydroxide molten salt method. $\mathrm{J}$ Cryst Growth 2013;381:153-9. 


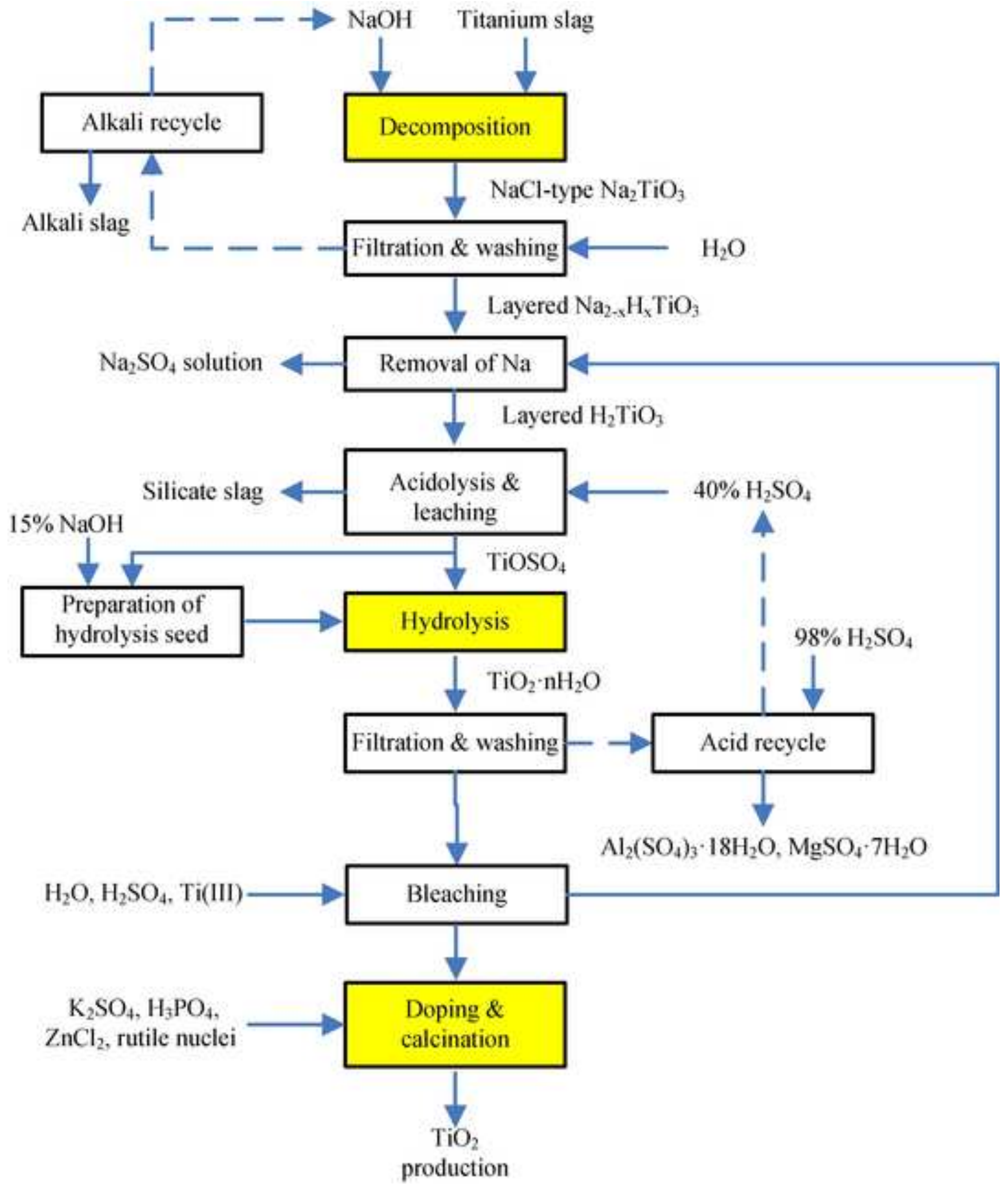




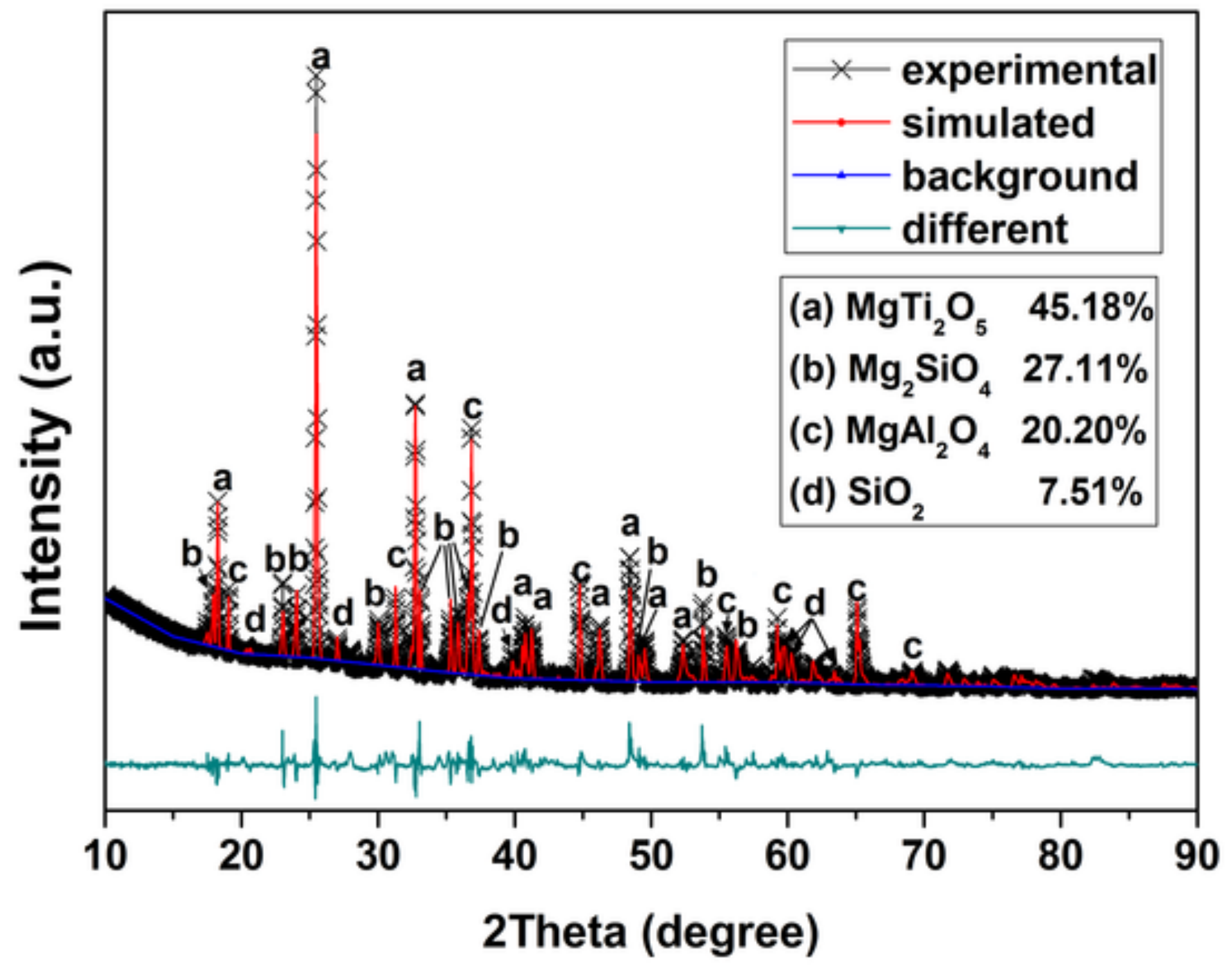




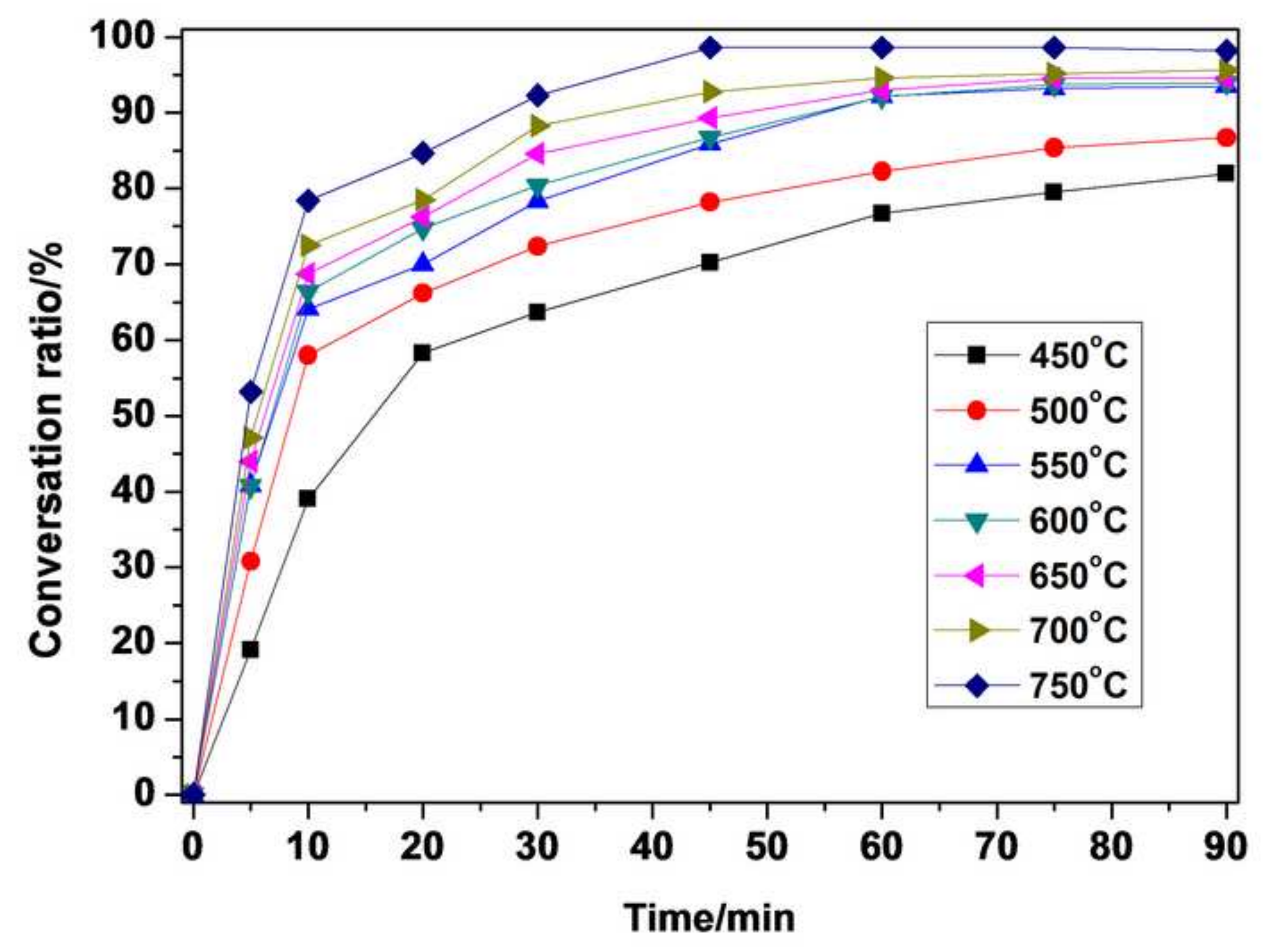




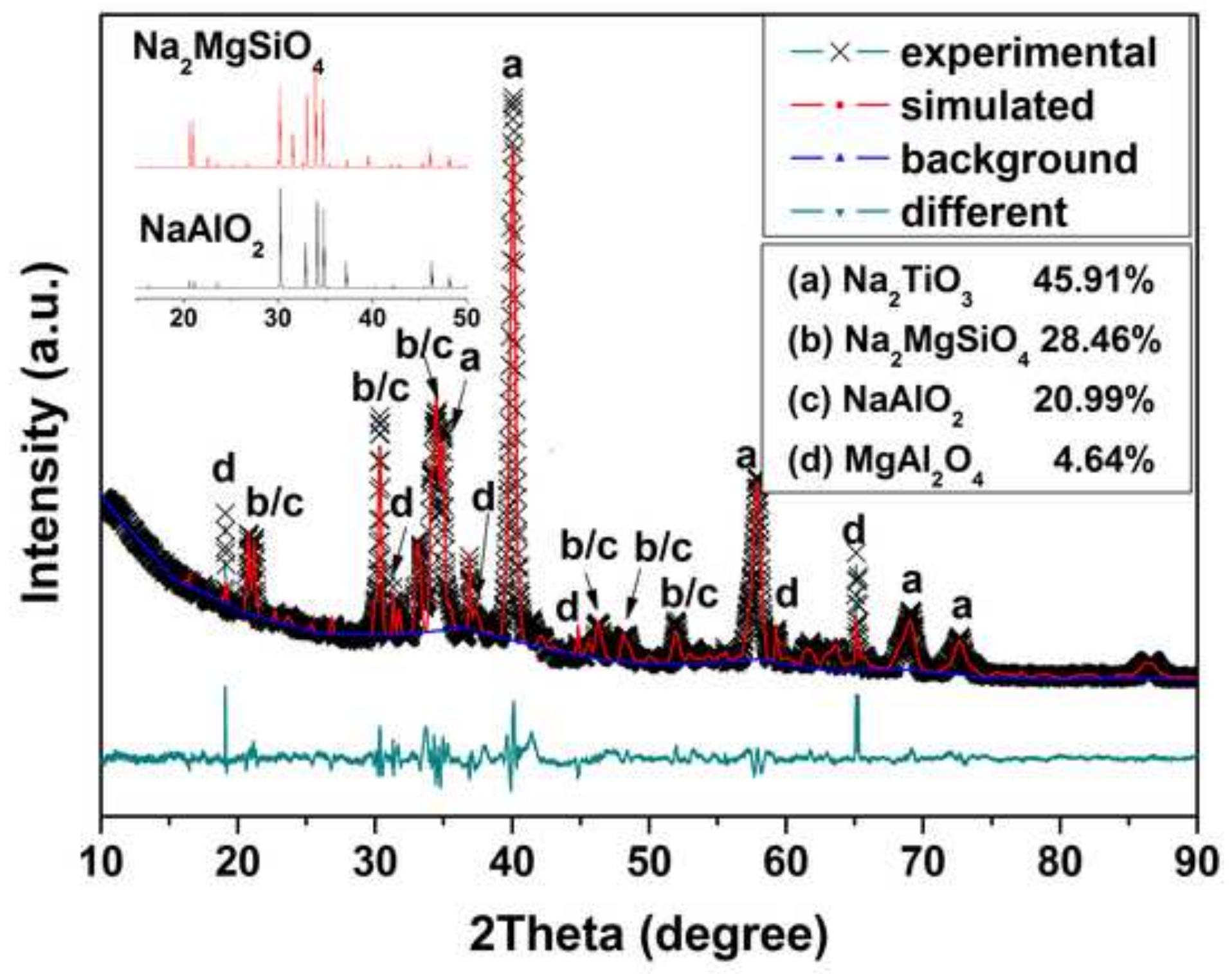




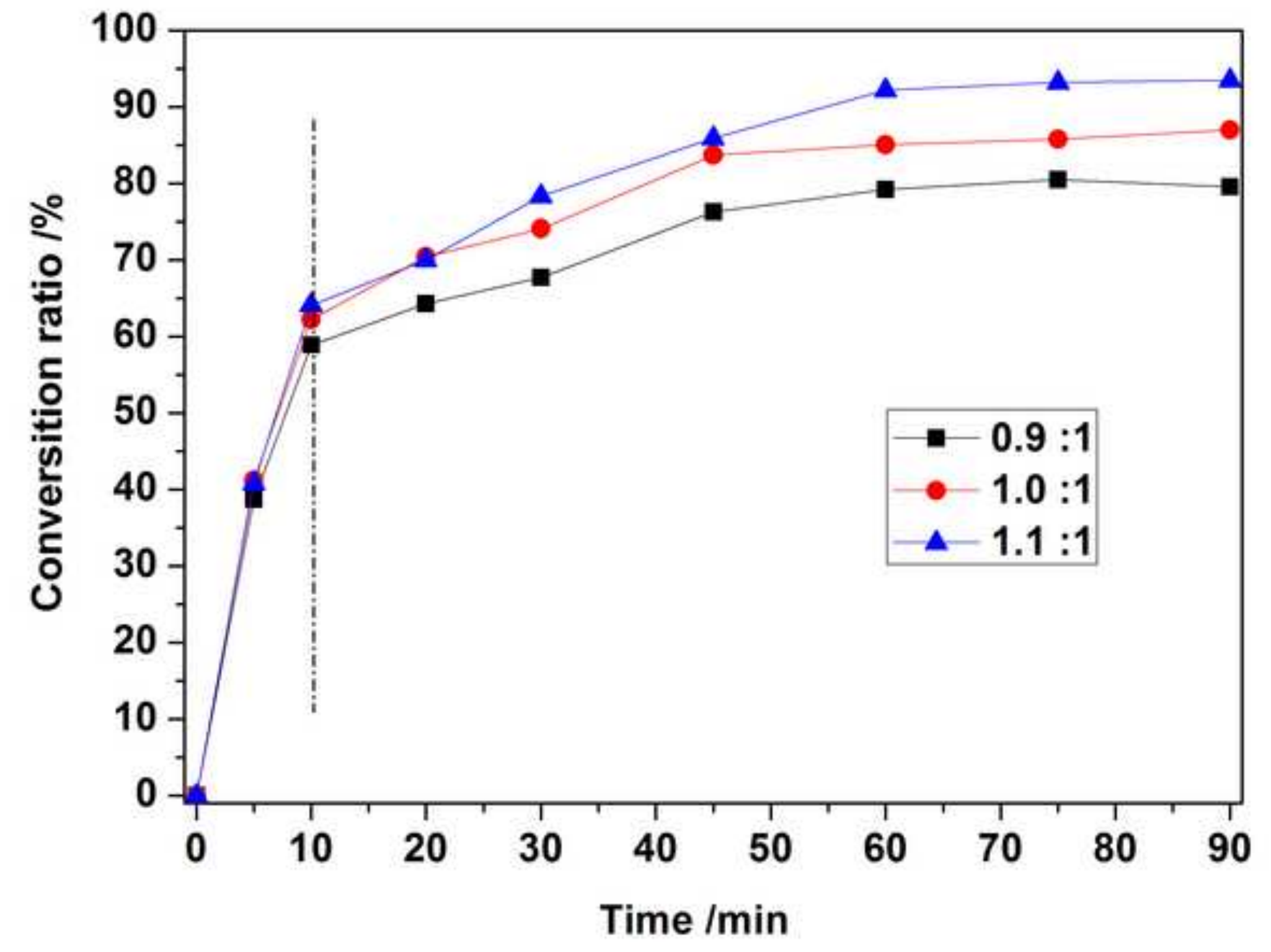




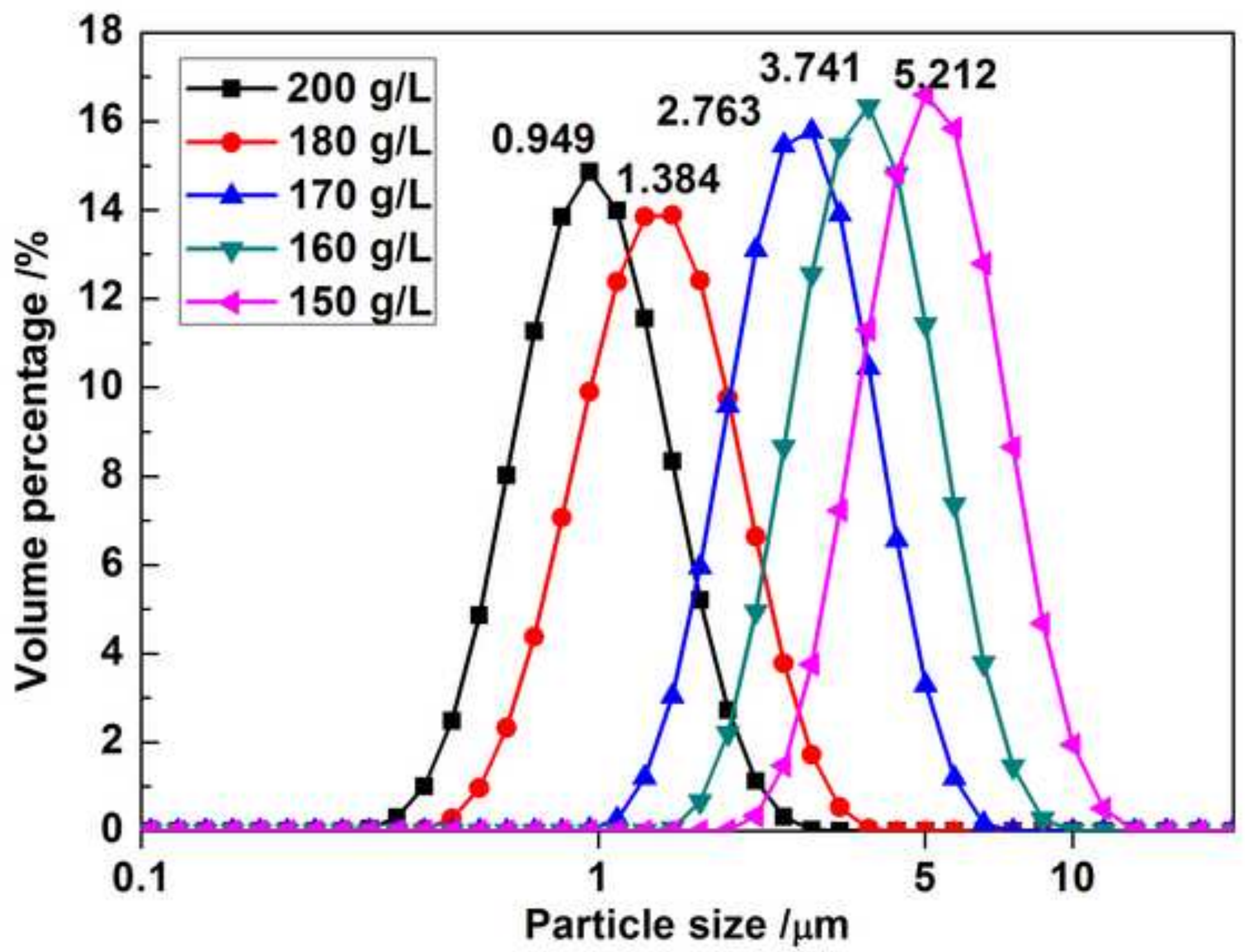




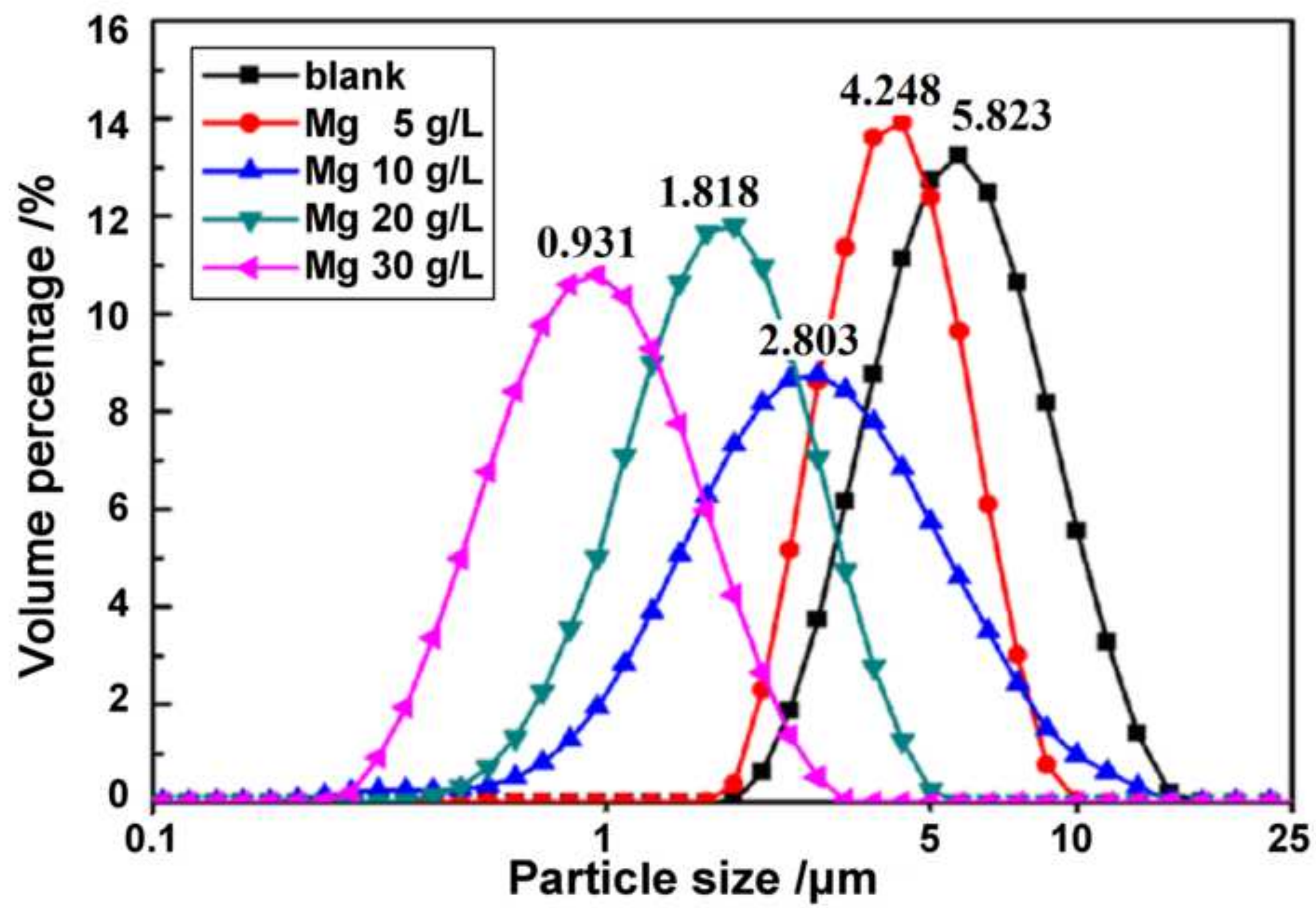




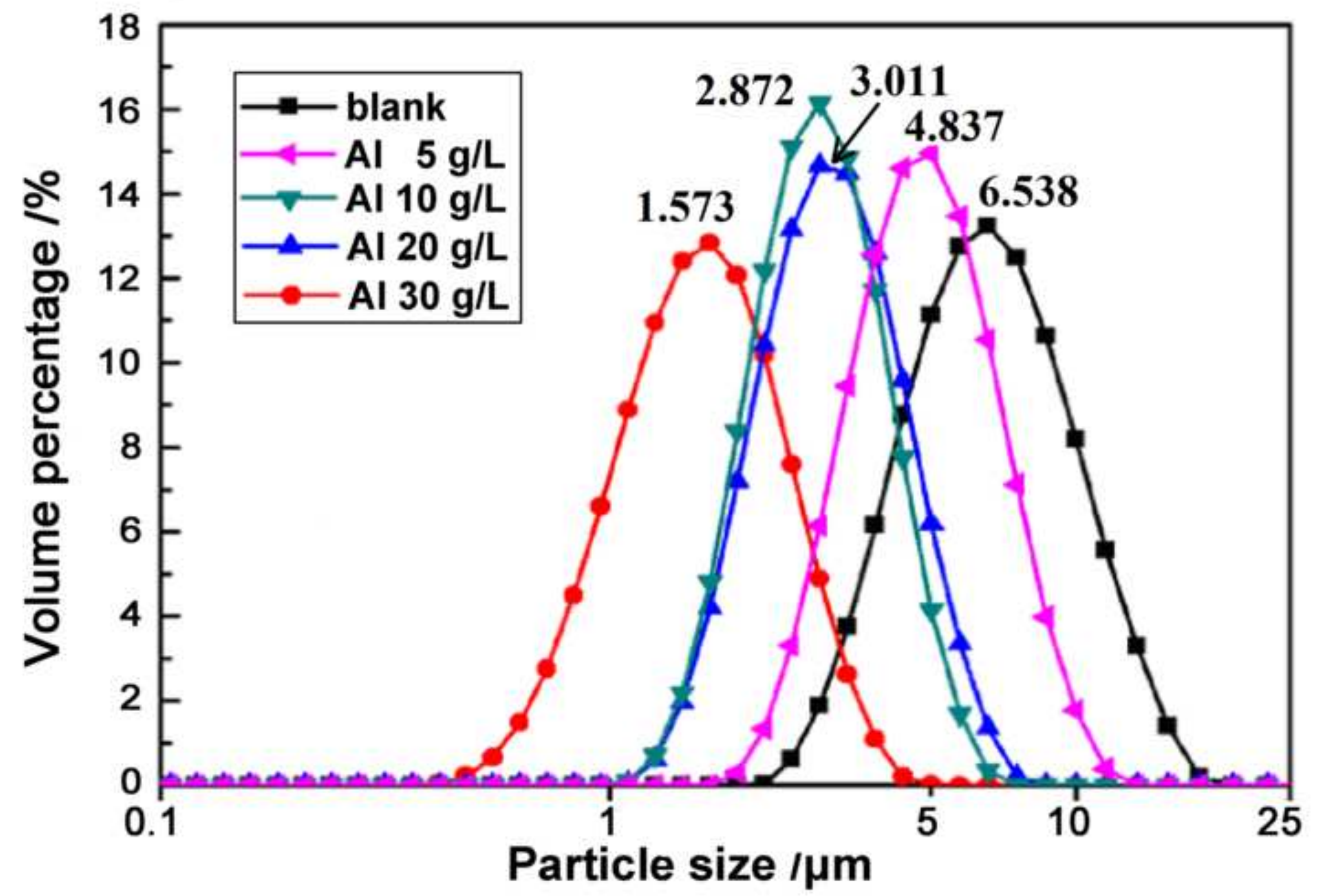

